\title{
ISTILAH-ISTILAH YANG DIGUNAKAN DALAM RITUAL SORONG SERAH AJI KRAMA MASYARAKAT SUKU SASAK: SEBUAH KAJIAN ETNOLINGUISTIK
}

\author{
Baiq Yuliatin Ihsani', Nina ${ }^{2}$ \\ 1,2 Dosen Program Studi Pendidikan Bahasa dan Sastra Indonesia \\ FKIP Universitas Muhammadiyah Mataram \\ baiqyulia120789@gmail.com
}

\begin{abstract}
ABSTRAK
Tujuan penelitian ini adalah untuk mendeskripsikan bentuk, fungsi, dan makna yang terkandung dalam ritual sorong serah Aji Krama masyarakat suku Sasak di Kecamatan Pujut, Lombok Tengah. Metode yang digunakan dalam mencapai tujuan tersebut, meliputi 1) metode penentuan subjek penelitian, 2) metode pengumpulan data, dan 3) metode analisis data. Metode penentuan subjek penelitian menggunakan purposive sampling yaitu memilih informan sesuai dengan tujuan penelitian. Metode pengumpulan data yang digunakan adalah metode observasi, metode wawancara, dan metode dokumentasi. Analisis data dilakukan dengan membuat reduksi data dengan cara abstraksi yaitu mengambil data yang sesuai dengan konteks penelitian dan mengabaikan data yang tidak diperlukan. Berdasarkan hasil analisis data, dapat disimpulkan bahwa bentuk-bentuk leksikon yang terdapat dalam ritual SSAK masyarakat suku Sasak di Kecamatan Pujut terdiri dari kata dasar, kata jadian, dan kelompok kata (frasa). Makna leksikon yang terdapat dalam penelitian ini meliputi 1) makna linguistik yaitu makna leksikal dan makna gramatikal (kata berimbuhan, kata ulang, dan kelompok kata), 2) makna kultural (budaya), yaitu lebih mengutamakan nilai-nilai agama dan moral. Secara umum makna kultural yang terdapat dalam leksikon tersebut berupa nilai religi, sosial, dan moral. Ritual SSAK berfungsi sebagai pedoman kehidupan bersama, yaitu untuk mengatur masyarakat dalam bertindak dan berbuat dalam menentukan sikap.
\end{abstract}

Kata kunci: etnolinguistik, ritual SSAK, bahasa, budaya

\section{PENDAHULUAN}

Budaya merupakan ciri khas suatu masyarakat. Untuk itu, budaya perlu dijaga keberadaannya agar tidak "ditelan" oleh zaman. Namun, kenyataannya budaya yang telah menjadi warisan para leluhur mulai terkikis karena pengaruh zaman. Fenomena ini terjadi pada masyarakat Suku Sasak. Dalam masyarakat Suku Sasak dikenal adanya budaya Sorong Serah Aji Krama (SSAK). SSAK merupakan salah satu ritual yang dilaksanakan dalam proses perkawinan masyarakat Suku Sasak. Ritual ini dianggap sakral oleh masyarakat Suku Sasak karena suatu pernikahan tidak dianggap sah dan melanggar norma apabila belum melaksanakan SSAK.

Hasil observasi dan keterangan dari beberapa tokoh adat, ritual SSAK telah mengalami pergeseran baik dari segi pelaksanaan, fungsi dan maknanya. SSAK tidak lagi dilaksanakan seperti 
yang diwariskan leluhurnya, tetapi sudah dimodifikasi sehingga keasliannya tidak lagi terjaga. Kecendrungan masyarakat Suku Sasak menginginkan proses SSAK yang simpel dan tidak rumit membuat ritual SSAK tidak terjaga keasliannya. Kondisi ini tentunya sangatlah memprihatinkan karena sebagaimana yang telah diungkapkan di atas bahwa budaya yang hilang akan turut menghilangkan bahasa yang mengacu pada budaya tersebut. Dengan kalimat lain dapat dikatakan bahwa budaya yang hilang akan turut menghilangkan istilahistilah yang mengacu pada budaya tersebut. Oleh sebab itu, penelitian ini sangat penting untuk dilakukan dengan tujuan untuk menjaga bahasa dan budaya yang mulai bergeser oleh pengaruh zaman.

Bahasa dan budaya dapat diteliti secara bersama-sama melalui persfektif etnolinguistik. Konsep etnolinguistik digunakan dalam penelitian ini dengan asumsi bahwa setiap etnis memiliki banyak leksikon/istilah penduduk asli yang digunakan oleh masyarakat dalam kebudayaannya. Etnolinguistik mengkaji bentuk linguistik yang mengungkapkan unsur kehidupan sosial dan menghubungkan bentuk bahasa dengan kebiasaan (budaya).

Berdasarkan penjelasan di atas, permasalahan yang menjadi dasar penelitian ini adalah penulis mengkaji bentuk, fungsi, dan makna istilah-istilah yang digunakan dalam ritual Sorong Serah Aji Krama masyarakat Suku Sasak ditinjau dari perspektif etnolinguistik. Adapun tujuan penelitian adalah untuk mendeskripsikan bentuk, fungsi, dan makna leksikon yang digunakan dalam ritual SSAK. Sesuai dengan dasar teori yaitu etnolinguistik, maka bentuk, fungsi, dan makna istilah-istilah yang dikaji dalam penelitian ini ditinjau dari aspek linguistik dan non linguistik. Penelitian ini diharapkan dapat memberikan kontribusi bagi daerah setempat dalam rangka menjaga bahasa dan budaya agar terhindar dari kepunahan.

\section{METODE PENELITIAN \\ Populasi dan Sampel}

Populasi penelitian ini adalah masyarakat yang terdapat di daerah penelitian. Metode penentuan subjek penelitian yang digunakan dalam pelaksanaan penelitian di lapangan adalah metode sampling, artinya bahwa tidak semua masyarakat di desa tersebut dijadikan sebagai informan. Beberapa informan ditetapkan sebagai wakil seluruh populasi yang diteliti dengan memperhatikan jenis data yang dibutuhkan dari informan. Teknik yang digunakan untuk menentukan jumlah anggota sampel dan individu yang ditetapkan sebagai informan adalah teknik purposive sample yaitu sampel dipilih bergantung pada tujuan penelitian tanpa memperhatikan kemampuan generalisasinya dan pengumpulan data diakhiri apabila peneliti tidak lagi menemukan informasi baru.

\section{Metode Pengumpulan Data}

\section{1) Metode Observasi}

Metode observasi dilakukan untuk memperoleh gambaran nyata suatu peristiwa atau kejadian untuk menjawab masalah penelitian. Dalam hal ini teknik yang digunakan adalah observasi partipasi yaitu peneliti terlibat langsung dalam pengamatan objek penelitian.

\section{2) Metode Wawancara}


Metode wawancara adalah metode yang digunakan peneliti untuk memperoleh data dengan cara berkomunikasi atau berinteraksi dengan narasumber atau subjek penelitian. Metode wawancara digunakan untuk memperoleh data primer yaitu data utama yang dibutuhkan untuk menjawab masalah penelitian. Teknik wawancara yang digunakan dalam penelitian ini adalah wawancara mendalam. Wawancara mendalam (in-depth interview) adalah proses memperoleh keterangan untuk tujuan penelitian dengan cara tanya jawab sambil bertatap muka antara pewawancara dengan informan atau orang yang diwawancarai, dengan atau tanpa menggunakan pedoman (guide) wawancara.

\section{3) Metode Dokumentasi}

Peneliti menggunakan metode dokumentasi yaitu pengumpulan data dengan cara mencari dokumen-dokumen yang terkait dengan penelitian. Dokumen dalam penelitian ini dapat berupa gambar atau foto dan dokumen lainnya yang dapat membantu mempercepat proses penelitian.

\section{Metode Analisis Data}

Dalam penelitian ini, peneliti menggunakan metode deskriptif kualitatif dalam menganalisis data. Data yang diperoleh melalui wawancara dianalisis menggunakan analisis deskritif kualitatif yaitu dengan cara mendeskripsikan data yang telah diperoleh dari hasil wawancara dengan informan secara menyeluruh. Peneliti menulis hasil wawancara dalam bentuk transkrip, selanjutnya peneliti membuat reduksi data dengan cara abstraksi yaitu mengambil data yang sesuai dengan konteks penelitian dan mengabaikan data yang tidak diperlukan. Selanjutnya, peneliti menganalisis sesuai dengan rumusan masalah ada dalam penelitian ini sehingga dapat disimpulkan.

\section{Rancangan Penelitian}

Adapun bentuk abstraksi rancangan penelitian yang telah dijelaskan di atas dapat dicermati dalam bagan berikut ini.

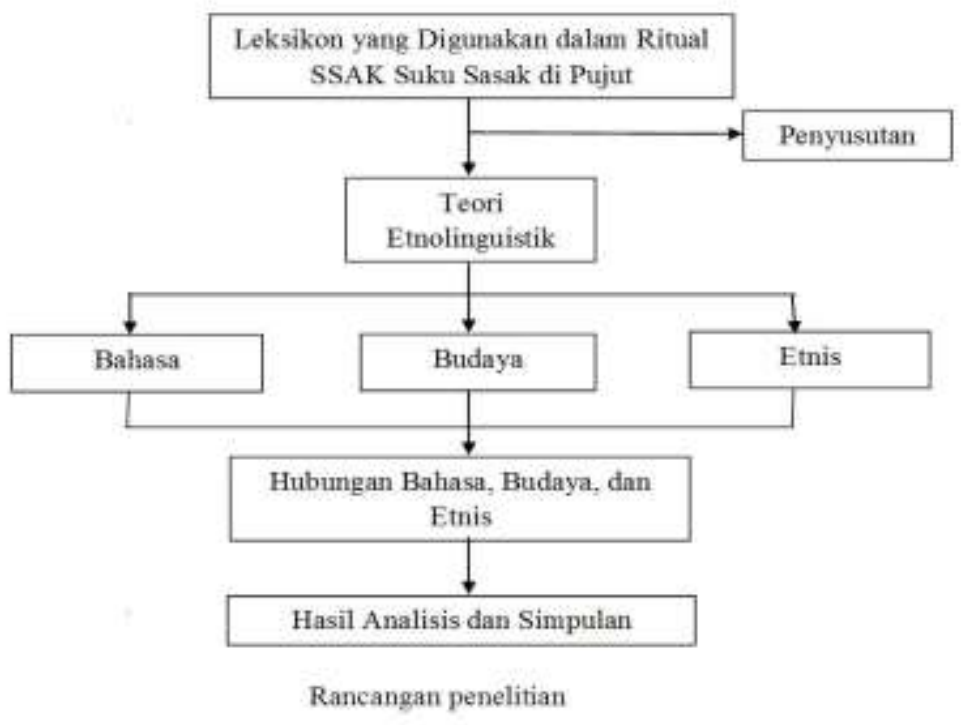




\section{PEMBAHASAN}

\section{Hakikat Sorong Serah Aji Krama}

Sorong serah merupakan acara inti dari sistem pernikahan masyarakat SS di Kecamatan Pujut. Acara sorong serah dilaksanakan ketika laki-laki dan perempuan sudah menikah dan sah sebagai suami istri. Secara khusus, acara sorong serah merupakan realisasi dari hasil perundingan pada acara rebaq pucuk. Sorong serah juga bisa dikatakan sebagai pertemuan antara keluarga pihak laki-laki dan keluarga pihak perempuan. Pada acara inilah, kedua keluarga belah pihak saling menerima dan mengakui bahwa masing-masing pihak telah menjadi keluarga besar. Hal berarti bahwa pernikahan itu tidak saja menyatukan antara laki-laki dan perempuan sebagai sepasang suami istri, tetapi juga menyatukan dua buah keluarga, baik itu dari keluarga pihak laki-laki maupun keluarga perempuan.

Aji krama adalah wujud proteksi yang diserahkan pada upacara sorong serah. Aji krama merupakan puncak acara pada adat perkawinan masyarakat SS di Kecamatan Pujut. Aji Krama merupakan adat budaya SS yang bersifat sakral, artinya sangat melekat pada adat budaya perkawinan masyarakat SS. Kegiatan ini dilaksanakan setelah pernikahan antara laki-laki dan perempuan secara agama Islam. Acara ini tidak cukup dengan acara akad nikah saja, tetapi dilanjutkan dengan proses sorong serah aji krama.

\section{Bentuk-bentuk Leksikon yang Digunakan dalam Ritual Sorong Serah Aji Krama}

Dalam ritual SSAK masyarakat Suku Sasak, terdapat beberapa istilah atau leksikon yang digunakan dalam menyebut berbagai rangkaian acara dan lambangnya. Menurut narasumber (Saladin, 63), proses adat ini harus dilaksanakan sebagai pengukuhan jati diri masyarakat Suku Sasak. Berikut dijelaskan istilah-istilah atau leksikon yang digunakan dalam ritual SSAK masyarakat Suku Sasak.

1. Sesirah/Otak Bebeli

Sesirah berasal dari kata sirah yang artinya kepala. Sesirah berfungsi melambangkan jati diri dan nilai yang melekat pada keluarga pengantin pria secara turun menurun. Sesirah biasanya ditandai dengan benda seperti emas, perak atau perunggu. Pemakain logam mulia ini akan disesuaikan dengan status sosial keluarga pengantin pria.

2. Napak Lemah

Napak lemah berasal dari dua kata yaitu kata napak yang berarti kaki dan lemah yang berarti tanah. Napak lemah bermakna menginjakkan kaki di tanah. Napak lemah dapat didefinisikan sebagai menginjak tanah atau sepasang pengantin sudah memiliki alamat yang jelas dan siap membangun rumah tangga. Napak lemah umumnya diwujudkan dalam bentuk uang logam, emas atau logam mulia. Uang tersebut melambangkan bahwa sang suami harus mampu meberikan nafkah kepada istrinya.

3. Olen-Olen

Kata olen-olen berasal dari kata len-len atau lian-lian yang berarti lain-lain atau berbeda. Olen-olen terdiri atas sejumlah kain yang yang diikat dengan selendang dan diletakkan pada sebuah peti. Olen- 
olen dilambangkan dengan kain yang memiliki makna yaitu bahwa sang suami harus mampu memberikan sandang atau pakaian kepada istrinya.

4. Arte Gegawan

Dalam pelaksanaan acara sorong serah Aji Krama haruslah dilengkapi dengan benda-benda yang disebut arte gegawan. Arte gegawan memiliki makna barang-barang bawaan. Arte gegawan terdiri uang dan barang-barang yang memiliki filosofi tersendiri bagi masyarakat suku Sasak.

5. Salin Dede

Istilah salin dede berasal dari dua kata, yaitu salin dan dede. Kata salin memiliki arti mengganti sedangkan kata dede berarti mangasuh. Jadi, salin dede memiliki pengertian mengganti untuk mengasuh. Adapun wujud dari salin dede ini adalah kain umbaq, ponjol, ceraken, kedogan (sabuk nganak), semprong tereng,kain putih, benang kataq dan pisau kecil untuk khitanan. Makna utama yang diwakili oleh salin dede dalam kegiatan upacara adat Sorong Serah Aji Krama adalah serah terima tanggung jawab dari pihak keluarga pengantin wanita kepada suaminya.

6. Pemecat Sengkang

Wujud benda yang digunakan untuk pemecat sengkang adalah anting emas yang diletakkan pada sebuah nampan kecil. Filosofinya adalah bagi masyarakat suku Sasak, seorang wanita yang sudah menikah tidak diperbolehkan lagi menggunakan anting sebagai perhiasan.
7. Penjaruman

Selain benda-benda di atas, dalam ucara ritual Sorong serah Aji Krama terdapat sebuah benda berupa jarum dan benang. Benda ini dinamakan penjaruman.

8. Pelengkak

Pelengkaq merupakan denda yang dikenakan kepada pihak pengantin laki-laki yang telah menikahi seorang gadis yang masih memiliki kakak belum menikah.

9. Babas Kuta

Babas kuta artinya melewati perbatasan. Jadi, babas kuta merupakan istilah yang digunakan untuk menyebut uang yang diberikan kepada pihak perempuan karena perempuan tersebut menikah dengan laki-laki yang berasal dari luar desa.

10. Krama Desa

Krama desa adalah salah satu kewajiban yang harus ditanggung oleh pihak pengantin laki-laki sehubungan dengan telah membawa seorang gadis dari sebuah desa untuk dijadikan istrinya.

11. Kor Jiwa

Seperti halnya krama desa, kor jiwa merupakan salah satu kewajiban yang harus dibayarkan oleh pihak keluarga pengantin laki-laki sebagai bentuk ganti rugi kepada kampung yang telah kehilangan warga sebab salah satu warganya diambil oleh pihak keluarga pengantin laki-laki.

12. Pecanangan/Penginang/Karas

Pecanangan merupakan tempat diletakkannya kapur, sirih, pinang, gambir dan tembakau. Pecanangan dibawa ketika kegiatan ritual sorong serah aji karma dilakukan sebagai lambang bahwa anak perempuannya 
akan menikah denga laki-laki pilihannya.

13. Lanjaran

Lanjaran/rokok merupakan perlengkapan adat yang harus tetap ada. Biasanya, rokok yang digunakan dalam acara adat sorong serah adalah rokok yang terbuat dari tembakau dilapisi dengan daun jagung.

14. Pudak Arum

Pudak Arum merupakan kain putih atau istilah dalam masyarakat suku Sasak disebut sapuq pengarat. Kain ini diperuntukkan kepada kepala dusun (Kadus) sebagai pemimpin yang telah memberikan jaminan keselamatan bagi rakyatnya. Oleh karena itu, suatu kewajaran untuk memberikan penghargaan cindera mata yang berupa kain putih yang akan digunakan sebagai ikat kepala (sapuq).

15. Ceraken

Ceraken adalah lambang kesehatan bagi kedua pengantin. Ceraken diisi dengan reragian, seperti sekuh (kencur) dan kunyiq (kunyit) untuk obat-obatan. Jaum (jarum) untuk menjahit yang bermakna memperbaiki hubungan apabila terjadi tidak saling memahami sesama pasangan, ladik (pisau) yang bermakna menjaga diri, semprong yang bermakna sebagai penerang dalam kehidupan, bawang yang bermakna mengantisipasi cemoohan bagi wanita dengan katakata "Kamu Endeqbi uah te bayah isiq bawang embus" atau menjaga jangan sampai menyinggung perasaan orang lain.

16. Pemegat
Pemegat atau sering juga disebut dengan pemutus pebaos. Pemegat ini dapat berupa uang yang dibagi-bagikan kepada semua yang hadir menyaksikan penyerahan aji krama.

17. Pencanang/Penjambeqan

Pencanangan atau penjambeqan merupakan suguhan perdana terhadap para tamu. Jika dalam ritual sorong serah Aji Krama tidak ada penjambeqan atau menyuguhkan rokok lekes (sirih) berarti masyarakat tersebut dianggap tidak tahu Adat. Penjambeqan atau mamaq tersebut dapat juga digunakan sebagai obat jika orang sakit mual perut dan lainnya.

18. Rombong

Rombong adalah lambang rumah tangga kedua pengantin. Rombong ini ditandai dengan ponjol besar (bakul nasi) berisi beras, padi, uang, dan sebagainya. Rombong juga dilengkapi dengan cobek, centong, dua ekor ayam (jantan dan betina) yang melambangkan sebagai kegiatan beternak, sedangkan kelapa, jagung, dan padi melambangkan pertanian.

19. Laca-laca

Laca-laca berarti jarak atau
batas. Laca-laca biasanya dilambangkan dengan anak alu (alu). Alu adalah sepotong kayu yang digunakan untuk menumbuk padi pada lesung. Laca-laca memiliki filosofi bahwa jika kita melewati batas bahkan sampai menginjak alu, tidak menutup kemungkinan alunya terkulir yang mengakibatkan kita terjatuh. 
20. Pisolo

Pisolo berarti utusan atau duta yang bertugas untuk menanyakan kesiapan wanita untuk menerima kedatangan rombongan penyorong. Persiapan yang dimaksud dalam hal ini adalah tempat diadakan ritual sorong serah Aji Krama dan kehadiran keluarga dan undangan.

21. Pembayun

Pembayun merupakan ketua rombongan yang mengawasi dan membimbing ritual sorong serah Aji Krama agar selalu menunjukkan sikap sopan santun selama acara berlangsung. Pembayun merupakan orang Aji Krama yang dipilih untuk mewakili atau menjadi juru bicara dalam acara sorong serah. Seseorang dikatakan pembayun apabila mengetahui tentang adat istiadat dan mampu berbahasa halus atau bahasa kawi. Pembayun ini disebut juga sebagai juru bicara pengantin lakilaki.

22. Penampi

Penampi merupakan juru bicara dari pihak pengantin wanita dalam rangka menerima, memutuskan tali jinah atas sorong serah Aji Krama pengantin laki-laki dan pengantin perempuan dengan kesepakatan keluarga kedua belah pihak. Penampi ini dilengkapi dengan sebuah tempat atau wadah berupa tikar atau alu yang diletakkan di tengah-tengah pembayun. Penampi dilengkapi oleh tokoh pengemban ugami, kepala desa, pengemban adat, serta wande warga.

23. Pemonggol

Pemonggol didefinisikan sebagai uang sorong serah yang diperuntukkan kepada seseorang yang bertugas mengawasi atau memimpin lingkungan. Dalam hal ini, orang yang dimaksud adalah kepala dusun.

24. Pengesap lasah

Pengesap lasah yaitu sejumlah uang yang diserahkan kepada orang tua pengantin perempuan sebagai bentuk haknya. Uang ini menyimbolkan bahwa uang tersebut diberikan sebagai ganti atau sebagai penyejuk karena rasa kekecewaannya ditinggal menikah oleh anak prempuannya.

25. Pengadap

Pengadap adalah orang yang menerima aji krama yang diserahkan oleh pihak laki-laki. Pengadap adalah keluarga pihak perempuan yang akan didatangi oleh pihak keluarga lakilaki dalam rangka acara sorong serah.

26. Pemapang

Pemapang merupakan orang yang akan menyambut kedatangan pihak keluarga laki-laki dan menerima aji krama yang diserahkan oleh pihak laki-laki.

\section{Fungsi Leksikon yang Digunakan dalam Ritual Sorong Serah Aji Krama Masyarakat Suku Sasak}

Berdasarkan data di atas, fungsi leksikon yang digunakan dalam ritual sorong serah Aji Krama masyarakat suku Sasak di Pulau Lombok adalah untuk menjaga kearifan lokal yang telah diwariskan oleh nenek moyang serta untuk memelihara kerukunan antarmasyarakat. Dengan adanya ritual sorong serah Aji Krama, masyarakat Lombok Tengah berkumpul di acara 
tersebut dengan tujuan membantu pasangan pengantin dalam melaksanakan semua proses ritual sorong serah Aji Krama. Dengan demikian, ritual sorong serah Aji Krama masyarakat suku Sasak berfungsi untuk menjunjung tinggi budaya masyarakat setempat yang ditandai dengan pengungkapkan nilai-nilai sosial dan agama melalui penggambaranpenggambaran, baik dalam bentuk benda maupun pemakaian bahasa.

Selain itu, fungsi lain dari ritual sorong serah Aji Krama adalah sebagai pedoman kehidupan bersama artinya bahwa budaya ritual sorong serah Aji Krama masyarakat suku Sasak berfungsi untuk mengatur masayarakat dalam bertindak dan berbuat dalam menentukan sikap. Sebagaimana yang telah dijelaskan sebelumnya bahwa ritual sorong serah Aji Krama berpedoman dari agama Islam. Hal ini juga berati bahwa masyarakat harus berperilaku sesuai dengan ajaran agama. Apabila melanggarnya, akan dikenakan sanksi adat sesuai dengan bentuk kesalahannya.

Berdasarkan penjelasan di atas, dapat disimpulkan bahwa ritual sorong serah Aji Krama masyarakat suku Sasak di Pulau Lombok memiliki fungsi yang sangat baik bagi kehidupan masyarakat setempat. Proses ritual sorong serah Aji Krama tersebut berfungsi meningkatkan hubungan baik dengan sesamanya yang diwujudkan dalam bentuk merelakan diri untuk ikut serta dalam semua rangkaian proses ritual SSAK. Selain itu, ritual sorong serah Aji Krama ini berfungsi sebagai pedoman hidup masyarakat setempat agar dapat bersikap dan bertingkah laku dengan baik dalam kehidupannya bermasyarakat. Dengan kalimat lain dapat dinyatakan bahwa ritual sorong serah Aji Krama tersebut sebagai pengatur masyarakat dalam berperilaku di lingkungan masyarakat agar senantiasa berbuat baik serta dapat menambah pemahaman masyarakat tentang pentingnya budaya sorong serah Aji Krama karena sarat akan nilai.

\section{Makna Leksikon yang Digunakan dalam Adat Perkawinan SS di Kecamatan Pujut}

Berdasarkan sudut pandang dalam mengkaji objek penelitian, makna leksikon yang dikemukakan dalam penelitian ini meliputi 1) makna linguistik yaitu makna leksikal dan makna gramatikal, 2) makna kultural (budaya). Makna leksikal bermaksud untuk mengungkapkan makna leksikon sebelum mengalami perubahan bentuk, sedangkan makna gramatikal bertujuan untuk mengungkapkan leksikon setelah mengalami proses gramatikalisasi, seperti pengimbuhan, pengulangan dan pemajemukan. Makna kultural yang ingin diungkapkan dalam penelitian ini adalah makna yang tersirat dari setiap leksikon yang digunakan dalam ritual sorong serah Aji Krama sebagai wujud dari budaya yang diciptakan oleh masyarakat suku Sasak di Pulau Lombok.

\section{Makna Linguistik}

Makna linguistik dimaksudkan untuk mengungkapkan makna leksikon yang terdapat dalam ritual sorong serah Aji Krama. Makna yang dimaksud adalah makna leksikal dan gramatikal.

Makna leksikal yang terdapat dalam leksikon ritual sorong serah Aji Krama dapat diuraikan sebagai berikut. 
1) Karas

Karas merupakan wadah tempat diletakkannya kapur, sirih, pinang, gambir dan tembakau.

2) Lanjaran

Lanjaran merupakan rokok yang terbuat dari tembakau dilapisi dengan daun jagung.

3) Ceraken

Ceraken merupakan wadah yang berisi dengan reragian (bumbubumbu), seperti sekuh (kencur), kunyiq (kunyit), jaum (jarum), ladik (pisau), semprong, dan bawang.

4) Rombong

Rombong merupakan ponjol besar (bakul nasi) berisi beras, padi, uang, cobek, centong, dua ekor ayam (jantan dan betina), kelapa, jagung, dan padi.

5) Pisolo

Pisolo merupakan utusan atau duta yang bertugas untuk menanyakan kesiapan wanita untuk menerima kedatangan rombongan penyorong.

6) Pembayun

Pembayun merupakan ketua rombongan yang mengawasi dan membimbing ritual sorong serah Aji Krama dari pihak pengantin laki-laki. Dengan kalimat lain dapat dikatakan bahwa pembayun merupakan orang Aji Krama yang dipilih untuk mewakili atau menjadi juru bicara dalam acara sorong serah Aji Krama.

7) Penampi

Penampi merupakan juru bicara dari pihak pengantin wanita dalam rangka menerima, memutuskan tali jinah atas sorong serah Aji Krama pengantin laki-laki dan pengantin perempuan dengan kesepakatan keluarga kedua belah pihak.
8) Pemonggol

Pemonggol didefinisikan sebagai uang sorong serah yang diperuntukkan kepada seseorang yang bertugas mengawasi atau memimpin lingkungan. Dalam hal ini, orang yang dimaksud adalah kepala dusun.

9) Pengadap

Pengadap adalah keluarga pihak perempuan yang menerima Aji Krama yang diserahkan oleh pihak laki-laki.

10) Pemapang

Pemapang merupakan orang yang akan menyambut kedatangan pihak keluarga laki-laki dan menerima Aji Krama yang diserahkan oleh pihak laki-laki.

Makna gramatikal berupa kata berimbuhan yang terdapat dalam leksikon ritual sorong serah Aji Krama dapat diuaraikan sebagai berikut.

1. Sesirah/Otak Bebeli

Sesirah berasal dari kata sirah yang artinya kepala yang biasanya ditandai dengan benda seperti emas, perak atau perunggu.

2. Penjaruman

Penjaruman berasal dari kata dasar jarum yang berarti sebuah benda berupa jarum dan benang.

3. Pelengkaq

Pelengkaq berasal dari kata lengkak yang berarti melangkahi. Pelengkak merupakan denda yang dikenakan kepada pihak pengantin laki-laki yang telah menikahi seorang gadis yang masih memiliki kakak belum menikah.

4. Pecanangan

Pecanangan berasal dari kata dasar canang yang berarti wadah tempat 
diletakkannya kapur, sirih, pinang, gambir dan tembakau.

5. Pemegat

Pemegat berasal dari kata dasar pegat yang artinya putus. Pemegat ini dapat berupa uang yang dibagibagikan kepada semua yang hadir menyaksikan penyerahan aji krama.

Makna gramatikal berupa kata ulang yang terdapat dalam leksikon ritual sorong serah Aji Krama masyarakat suku Sasak di Lombok yaitu sebagai berikut.

1. Olen-Olen

Kata olen-olen berasal dari kata len-len atau lian-lian yang berarti lain-lain atau berbeda. Olen-olen terdiri atas sejumlah kain yang yang diikat dengan selendang dan diletakkan pada sebuah peti.

2. Laca-laca

Laca-laca berarti jarak atau batas. Laca-laca biasanya dilambangkan dengan anak alu (alu). Alu adalah sepotong kayu yang digunakan untuk menumbuk padi pada lesung.

Makna gramatikal berupa kelompok kata (frasa) yang terdapat dalam leksikon ritual sorong serah Aji Krama masyarakat suku Sasak di Lombok dapat diuraikan sebagai berikut.

1. Otak Bebeli

Otak bebeli merupakan benda seperti emas, perak atau perunggu.

2. Napak Lemah

Napak lemah berasal dari dua kata yaitu kata napak yang berarti kaki dan lemah yang berarti tanah. Napak lemah bermakna menginjakkan kaki di tanah. Napak lemah dapat didefinisikan sebagai menginjak tanah atau sepasang pengantin sudah memiliki alamat yang jelas dan siap membangun rumah tangga.

3. Arte Gegawan

Arte gegawan merupakan barangbarang bawaan yang dibawa ketika acara sorong serah Aji Krama berlangsung.

4. Salin Dede

Istilah salin dede berasal dari dua kata, yaitu salin dan dede. Kata salin memiliki arti mengganti sedangkan kata dede berarti mangasuh. Jadi, salin dede memiliki pengertian mengganti untuk mengasuh. Makna utama yang diwakili oleh salin dede dalam kegiatan upacara adat Sorong Serah Aji Krama adalah serah terima tanggung jawab dari pihak keluarga pengantin wanita kepada suaminya.

5. Pemecat Sengkang

Pemecat Sengkang merupakan benda berupa ranting emas yang diletakkan pada sebuah nampan kecil.

6. Babas Kuta

Babas kuta artinya melewati perbatasan. Jadi, babas kuta merupakan istilah yang digunakan untuk menyebut uang yang diberikan kepada pihak perempuan karena perempuan tersebut menikah dengan laki-laki yang berasal dari luar desa.

7. Krama Desa

Krama desa adalah salah satu kewajiban yang harus ditanggung oleh pihak pengantin laki-laki sehubungan dengan telah membawa seorang gadis dari sebuah desa untuk dijadikan istrinya.

8. Kor Jiwa

Kor jiwa merupakan salah satu kewajiban yang harus dibayarkan oleh pihak keluarga pengantin lakilaki sebagai bentuk ganti rugi kepada 
kampung yang telah kehilangan warga sebab salah satu warganya diambil oleh pihak keluarga pengantin laki-laki.

9. Pudak Arum

Pudak Arum merupakan kain putih atau istilah dalam masyarakat suku Sasak disebut sapuq pengarat.

10. Pengesap lasah

Pengesap lasah yaitu sejumlah uang yang diserahkan kepada orang tua pengantin perempuan sebagai bentuk haknya.

\section{Makna Kultural}

Makna kultural yang dimaksud dalam penelitian ini adalah makna yang terkandung dalam budaya itu sendiri yaitu dalam ritual sorong serah Aji Krama masyarakat suku Sasak. Rangkaian proses ritual sorong serah Aji Krama tersebut mengandung berbagai makna dan filosofi yang mewakili cara masyarakat suku Sasak memandang lingkungan dan kehidupan di dalamnya. Berdasarkan data yang telah dipaparkan, dapat dikatakan bahwa makna kultural yang terdapat dalam ritual sorong serah Aji Krama berupa nilai religi, sosial, dan moral. Leksikon-leksikon yang terdapat dalam ritual sorong serah Aji Krama menunjukkan bahwa makna religi dan moral lebih ditonjolkan dalam pelaksanaan ritual sorong serah Aji Krama. Berdasarkan penjelasan mengenai leksikon-leksikon tersebut diketahui bahwa masyarakat suku Sasak budaya yang kental dan pemahaman agama yang mendalam.

Berdasarkan penjelasan di atas dapat disimpulkan bahwa masyarakat suku Sasak di dalam melaksanakan ritual sorong serah Aji Krama lebih mengutamakan nilai-nilai agama dan moral. Jadi, leksikon dalam ritual sorong serah Aji Krama mengandung makna kultural yang sangat bermanfaat bagi kehidupan sosial sebagai pedoman dalam menghadapi kehidupan bermasyarakat. Dengan adanya ritual sorong serah Aji Krama dapat menambah pemahaman warga tentang pentingnya agama dan menjunjung tinggi nilai moral yang terkandung dalam setiap simbol yang digunakan dalam ritual sorong serah Aji Krama.

Semua proses dalam ritual sorong serah Aji Krama merujuk pada agama Islam. Ajaran Islam dijadikan pedoman dalam melaksanakan proses adat perkawinan. Dengan demikian, dalam ritual sorong serah Aji Krama memiliki makna religius. Makna religius yang dapat diperoleh dari ritual sorong serah Aji Krama ini adalah mengutamakan kebersamaan dan senantiasa menjaga hubungan baik antar sesama.

\section{PENUTUP}

Berdasarkan pembahasan di atas dapat disimpulkan bahwa bentuk-bentuk leksikon yang terdapat dalam ritual SSAK masyarakat suku Sasak di Kecamatan Pujut terdiri dari kata dasar, kata jadian, dan kelompok kata (frasa). Makna leksikon yang terdapat dalam penelitian ini meliputi 1) makna linguistik yaitu makna leksikal dan makna gramatikal (kata berimbuhan, kata ulang, dan kelompok kata), 2) makna kultural (budaya), yaitu lebih mengutamakan nilai-nilai agama dan moral. Secara umum makna kultural yang terdapat dalam leksikon tersebut berupa nilai religi, sosial, dan moral. Ritual SSAK berfungsi sebagai pedoman kehidupan 
bersama, yaitu untuk mengatur masyarakat dalam bertindak dan berbuat dalam menentukan sikap.

\section{DAFTAR PUSTAKA}

Abdullah, W. 2013. Etnolinguistik: Teori, Metode dan Aplikasinya. Solo: Universitas Sebelas Maret Surakarta.

Afini, F.N. 2015. Leksikon Tumbuhan dalam Peribahasa Jawa (Kajian Etnolinguistik). Semarang: UNS.

Barker, Chris. 2005. Cultural Studies Teori dan Praktek. (Diterjemahkan dari Cultural Studies: Theory and Practise SAGE Publication, London, 2000). Yogyakarta: BENTANG (PT Bentang Pustaka).

Booij, G. 2010. Gramatika Kata: Sebuah

Pengantar Morfologi.
(Diterjemahkan dari The
Grammar Of Words an
Introduction to Morphology
oleh Sukri dan Nuriadi. 2007.
New York: Oxford University
Press). Mataram: Cerdas Press
Mataram.

Chaer, A. 2008. Morfologi Bahasa Indonesia: Pendekatan Proses. Jakarta: Rineka Cipta.

Chaer dan Agustina. 2010. Sosiolingustik: Perkenalan Awal.Jakarta: Rineka Cipta.

Duranti, A. 1997. Linguistic Anthropology. Cambridge: Cambridge University Press.

Gonda, J. 1988. Linguistik Bahasa Nusantara: Kumpulan Karya. Jakarta: Balai Pustaka.

Haryanti, D. dan Agus B.W. 2007. "Ungkapan Etnis Petani Jawa di Desa Japanan, Kecamatan Cawas,
Kabupaten Klaten: Kajian

Etnolinguistik." Kajian Linguistik dan Sastra, Vol. 19, No. 1. Juni 2007.

Koentjaraningrat. 1974. Kebudaanyaan, Mentalitet, dan Pembangunan. Jakarta: Gramedia.

Kridalaksana, H. 2001. KamusLinguistik. Jakarta: Gramedia.

Kurniati, T.S. 2013. Wacana dala Adat Perkawinan Sorong Serah Aji Krama di Kalangan Masyarakat Sasak, Lombok Timur, Nusa Tenggara Barat: Sebuah Kajian Etnolinguistik (Tesis). Yogyakarta: UGM.

Mangkey, dkk. 2010. Kebudayaan Minahasa: Kajian Etnolinguistik Tentang Konstruk Nilai Budaya Lokal Menghadapi Persaingan Global. Interlingua Vol 42010.

Mbete, A.M. 2007. "Ekologi Bahasa". Bahan Matrikulasi Program Magister Linguistik PPs Universitas Udayana 2007. . 2008. "Bahasa dan Budaya Lokal Minoritas: Asal-Muasal, Ancaman Kepunahan, dan Ancangan Pemberdayaan dalam Kerangka Pola Ilmiah Pokok Kebudayaan Universitas Udayana". Pidato pengukuhan jabatan guru besar tetap dalam bidang linguistik pada Fakultas Sastra Universitas Udayana 25 Oktober 2003.

Moleong. L.J. 2013. Metodologi Penelitian Kualititatif. Bandung: PT Remaja Rosdakarya Offset.

Mulyono. 2013. Ilmu Bahasa Indonesia Morfologi: Teori dan Sejumput Problematik Terapannya. Bandung: Yrama Widya. 
Murcahyanto, H. 2015. Leksikon Pembentuk Tingkat Tutur pada Upacara Adat Sorong Serah Aji Krama di Desa Sakra Kabupaten Lombok Timur. Jurnal Educatio Vol 1 No 1. Lombok Timur: STKIP Hamzanwadi.

Pratiknyo, A. 2009. Istilah-istilah Upacara Perkawinan Adat Jawa Bubak Kawah dan Tumplak Punjen di Kecamatan Bendosari Kabupaten Sukoharjo: Suatu Kajian Etnolinguistik: Skripsi. Surakarta: Universitas Sebelas Maret.

Pujiyatno. 2009. Istilah-Istilah Kekerabatan Masyarakat Kabupaten Kebumen: Sebuah Kajian Etnolinguistik. Leksika Vol 3 No 1 2009: 53 - 59.

Sibarani, R. 2004. Antropolinguistik. Medan: Poda.

Sukri, M. 2014. Tuturan Ritual Komunitas Wetu Telu Masyarakat Adat Bayan di Kabupaten Lombok Utara: Kajian Berdasarkan Pendekatan Pragmatik. Prosiding Seminar Nasional Prasasti Hal 46 - 51.

Suyitno, I. 2008. Kosakata Lagu Daerah Banyuwangi: Kajian Etnolinguistik Etnik Using. Humaniora Vol 20 $2008179-190$.

Wierzbicka, A. 1992. Semantics, Cultures, and Cognition: Universal Human Concepts in Culture-Specific Confirugation. New York: Oxford University Press 